УДК 582.475.4+581.522.4(477.63)

Н. Ю. Шевчук ${ }^{1,2}$, I. І. Коршиков ${ }^{1,2}$, Е. Р. Гусейнова ${ }^{2}$, Ю. М. Петрушкевич ${ }^{1}$, О. В. Красноштан ${ }^{1,2}$

1. Донещький ботанічний сад НАН України,

2. Криворізький ботанічний сад НАН Украӥни

\title{
РОЗПОВСЮДЖЕНІСТЬ ТА ЖИТТЕЗДАТНІСТЬ ВИДІВ РОДУ PINUS L. В НАСАДЖЕННЯХ М. КРИВОГО РОГУ
}

Вивчено життєздатність видів роду Pinus L. в насадженнях п'яти адміністративних районів м. Кривий Ріг. Досліджені соснові насадження знаходяться на вільних пришляхових територіях на відстані 5-20 м і більше від самої дороги або у скверах біля адмінбудівель, лікарень, шкіл, а також у парках. 3'ясовано, що в насадженнях міста найбільш представлені $P$. pallasiana - 340 дерев $(60,5 \%)$ і $P$. sylvestris - 210 дерев $(37,4 \%)$, а $P$. banksiana лише 12 дерев $(2,1 \%)$. Насадження $P$. pallasiana і $P$. sylvestris відзначаються високим рівнем життєвості, на відміну від P. banksiana. Найчисленнішою в насадженнях P. pallasiana є вікові групи 11-20 років - 135 особин, або 39,7 \%, і 21-30 років - 118 особин, або 34,7 \%. У насадженнях $P$. sylvestris найчисленніша вікова група 11-30 років, що становить 92,4 \% усіх дерев. P. banksiana в насадженнях міста зустрічається досить рідко - 12 дерев віком 10-20 років, які пригнічені у зрості і мають пошкоджений вигляд. В насадженнях $P$. pallasiana і $P$. sylvestris у вікових категоріях 15-19 і 25-30 років суттєвих відмінностей за висотою рослин і діаметром стовбура між деревами цих видів не спостерігається. Життсвий стан цих дерев характеризусться категорісю «здорові» і рідко «пошкоджені». В умовах міського парку «Шахтарський» знайдено 45-48-річні дерева P. pallasiana, які сягали 14 м у висоту при максимальному діаметрі стовбура на рівні 1,3 м - 43 см.

Ключові слова: види роду Pinus L., біометричні параметри, життєвий стан, урботехногенне середовище, м. Кривий Ріг.

Н. Ю. Шевчук ${ }^{1,2}$, И. И. Коршиков ${ }^{1,2}$, Э. Р. Гусейнова ${ }^{2}$, Ю. Н. Петрушкевич ${ }^{1}$, О. В. Красноштан ${ }^{1,2}$

1. Донеикий ботанический сад НАН Украины,

2. Криворожский ботанический сад НАН Украинь

\section{РАСПРОСТРАНЕННОСТЬ И ЖИЗНЕСПОСОБНОСТЬ ВИДОВ РОДА PINUS L. В НАСАЖДЕНИЯХ Г. КРИВОГО РОГА}

Изучена жизнеспособность видов рода Pinus L. в насаждениях пяти административных районов г. Кривого Рога. Исследованные сосновые насаждения находятся на свободных придорожных территориях на расстоянии 5-20 м и больше от самой дороги или в скверах около админзданий, больниц, школ, а также в парках. Выяснено, что в насаждениях города наиболее представлены $P$. pallasiana 340 деревьев (60,5\%) и P. sylvestris - 210 деревьев $(37,4 \%)$, а P. banksiana только 12 деревьев $(2,1 \%)$. Насаждения $P$. pallasiana и $P$. sylvestris отличаются высоким уровнем жизненности, в отличие от $\boldsymbol{P}$. banksiana. Самыми многочисленными в насаждениях P. pallasiana являются возрастные группы 11-20 лет - 135 особей или 39,7 \% и 21-30 лет -118 особей, или 34,7 \%. В насаждениях $P$. sylvestris самая многочисленная возрастная группа 11-30 лет, что составляет 92,4 \% от всех деревьев. P. banksiana в насаждениях города встречается достаточно редко - 12 деревьев возрастом 10-20 лет, которые угнетены в росте и имеют поврежденный вид. В насаждениях $P$. pallasiana и $P$. sylvestris в возрастных категориях 15-19 и 25-30 лет существенных отличий в высоту растений и диаметрах ствола не отмечается. Жизненное состояние этих деревьев характеризуется категориями «здоровые» и редко «поврежденные». В условиях городского парка «Шахтарский» найдены 45-48-летние деревья $P$. pallasiana, которые достигали 14 м в высоту при максимальном диаметре ствола на уровне 1,3 м - 43 см.

Ключевые слова: виды рода Pinus L., биометрические параметры, жизненное состояние, урботехногенная среда, г. Кривой Рог.

(C) Н. Ю. Шевчук, І. І. Коршиков, Е. Р. Гусейнова, Ю. М. Петрушкевич, О. В. Красноштан, 2017 


\section{N. Y. Shevchuk ${ }^{1,2}$, I. I. Korshikov ${ }^{1,2}$, E. R. Guseynova ${ }^{2}$, Y. N. Petrushkevich ${ }^{1}$, O. V. Krasnoshtan ${ }^{1,2}$ \\ 1. Donetsk Botanical Garden of NAS of the Ukraine, \\ 2. Kriviy Rih Botanical Garden of NAS of the Ukraine}

\section{THE SPREAD AND VIABILITY OF THE PINUS L. SPECIES IN THE KRIVIY RIH PLANTATIONS}

The viability of the Pinus $\mathrm{L}$. species has been studied in the 5 administrative regions of the Kriviy Rih city. Pine plantations were investigated at the free roadside territories, squares, administrative buildings, hospitals, schools and at the city parks also. It has been established that at the city plantations the most spread are: $P$. pallasiana - (around 340 trees were found) $(60,5 \%)$ and $P$. sylvestris - around 210 trees $(37,4 \%)$, along with that $P$. banksiana - only around 12 trees $(2,1 \%)$. The distribution of the trees according their age groups with interval in $\mathbf{1 0}$ years shows that the most spread group in the $\mathrm{P}$. pallasiana plantations is a group of 11-20 years-135 species or 39,7\% of the general amount of the plants and 21-30 years -118 species or 34,7\%. Trees $P$. pallasiana of the 11-30 years at the roadside plantations have $3 / 4$ of the total amount in the plantations, $P$. sylvestris $-92,4 \%$. At the last decade there was landings reduction of the both pine species to $0,9 \% P$. sylvestris and to $11,5 \% P$. pallasiana. It's hard to find $P$. banksiana in the city plantations, it was found 12 trees just, at the age of 10-20 years, these trees looked oppressed and damaged.

In the $P$. pallasiana and $P$. sylvestris at the age groups of 15-19 and 25-30 years there was no difference in the height of the trees (h) and trunk diameter (d) on the height $130 \mathrm{~cm}$. For the age group at $15-19$ years, $h=4,4-0,1 \mathrm{~m}, \mathrm{D}=15,8-0,4 \mathrm{~cm}(P$. pallasiana $)$ and $\mathrm{h}=5,0$ $4,0 \mathrm{~m}, \mathrm{D}=16,4-1,6 \mathrm{~cm}$ (P. sylvestris). The age group of $25-30$ years $\mathrm{h}=9,5-0,2 \mathrm{~m}, \mathrm{D}=\mathbf{2 7 , 9 -}$ $0,6 \mathrm{~cm}$ ( $P$. sylvestris). Living condition of these trees characterized as healthy and rarely damaged. At the city park conditions are found $45-\mathbf{4 8}$ years old trees of the $P$. pallasiana, that reached around $14 \mathrm{~m}$ in height with maximum trunk diameter $1,3 \mathrm{~m}-43 \mathrm{~cm}$.

Keywords: species of the Pinus L. genus, biometric parameters, living condition, urbotechnogenic environment, city Kriviy Rih.

У промислових містах степової зони України деревні рослини відіграють дуже важливу роль, насамперед значно поліпшують комфортність проживання населення. Зелені насадження, як елемент ландшафту, є важливою складовою у планувальній структурі міста і функціональній організації його простору та підвищенні художньої виразності архітектурних ансамблів, помітно впливають на оточуюче середовище $[1 ; 2 ; 4 ; 10 ; 16]$. Вони покращують екологічні, мікрокліматичні та санітарно-гігієнічні умови життя міського населення, сприяють формуванню культурного ландшафту сучасного міста [11]. Ці функції зелених насаджень набувають особливого значення у промислових містах, повітря яких наповнено пилом, аерозолями, токсичними газами, димом. Зелені насадження розглядаються в урбосистемах як умовні біофільтри, як важливий засіб оптимізації середовища, а при озелененні санітарно-захисних зон промислових підприємств як «зелений щит», що перешкоджає розповсюдженню аерополютантів у житлові квартали міст. Створення зелених насаджень у населених пунктах степової зони $\epsilon$ одним із ефективних заходів для рекреації, попередження негативних природних явищ та послаблення техногенного навантаження на довкілля.

Урботехногенне середовище в цілому істотно відрізняється від природних умов, за яких були сформовані і спадково закріплені еколого-фізіологічні особливості деревних рослин. Багато рослин в урбоекосистемах, як правило, вимушені пристосовуватися до несприятливих для них екологічних умов - забрудненого атмосферного повітря, недостатньої освітленості, своєрідного физико-хімічного складу міських грунтів та інших чинників середовища. Високий локальний рівень негативного впливу урботехногенних факторів нерідко призводить до зниження стійкості рослин, їх ослаблення, враження шкідниками та хворобами, зни- 
ження продуктивності та життєздатності і, як наслідок, до передчасного старіння та зменшення довговічності [7].

Серед найбільш розвинених промислових міст степової зони виділяється Кривий Ріг, найбільший і найстаріший центр із видобутку залізної руди. 3 причини розташування на Криворіжжі потужної гірничодобувної і переробної промисловості, цей регіон є одним з найбільш екологічно небезпечних в України. Серед викидів промислових підприємств Криворіжжя домінують токсичні для рослин оксиди сірки і азоту, сірководень, аміак та інші гази, органічні речовини.

Добір стійких до урботехногенного середовища видів деревних рослин, вивчення особливостей їх росту в сучасних умовах аридизації клімату є однією 3 важливих передумов для успішного розв'язання завдань із озеленення наших міст. У створенні зелених насаджень у промислових регіонах і містах степової зони України переважно використовують деревні рослини-інтродуценти. 3 другої половини XX століття для цього почали масово висаджувати хвойні, зокрема, види роду Pinus L. Серед різноманіття інтродуцентів окремі види цього роду вважаються перспективними 3 огляду на притаманні їм біоекологічні властивості посухостійкість, толерантність до трофності грунтів, мала залежність від їх родючості, достатня морозостійкість та загальновідомими санітарно-оздоровчими якостями [17]. Введення в насадження міст хвойних, стійких до промислового забруднення, довговічних зі стабільним декоративним ефектом на сьогодні є актуальним питанням. Підвищення стійкості та довговічності хвойних культур у міських насадженнях можливе на основі аналізу стану та їх життєздатності за умов техногенного забруднення.

Метою дослідження була оцінка життєздатності видів роду Pinus L. piзного віку в насадженнях міста Кривого Рогу.

Матеріали та методи досліджень. У п’яти адміністративних районах міста було обстежено насадження на пришляхових територіях 23 вулиць. Маршрутним методом досліджувався стан дерев Pinus pallasiana D. Don., P. sylvestris L. i $P$. banksiana Lamb. Визначено кількість особин, їхнє місцезростання, вік, діаметри стовбура, висоту дерев, площу проекції, об'єм крони та вік хвої з використанням мірної вилки, маятникового висотоміра Макарова (BM) [3; 13; 14]. Для оцінювання життєвого стану рослин використовували 5-бальну шкалу В. Т. Ярмішко [18]. Показники стану крон деревних рослин у міських насадженнях визначали за «Методичними рекомендаціями з моніторингу лісів України» [15]. Статистичну обробку отриманих результатів проведено з використанням пакета програм MC Excell [6].

Результати і їх обговорення. В озелененні міста Кривого Рогу використовуються три види роду Pinus - P. pallasiana, P. sylvestris та P. banksiana, які зростають поодиноко, у групових та рядових посадках на вільних пришляхових територіях.

В насадженнях міста найбільш представлено P. pallasiana, знайдено 340 дерев 3 562, що були обстежені для трьох видів роду Pinus L. Відповідно частка дерев цього виду становить $60,5 \%, P$. sylvestris $-37,4 \%$ і $P$. banksiana $-2,1 \%$. У п'яти адміністративних районах міста ці співвідношення між цими трьома видами змінювалися. Так, наприклад, мінімальне представництво P. pallasiana було $16,9 \%$, а максимальне - 73,3 \%. Стосовно P. sylvestris межі варіації становили $26,7-74,0 \%$, а P. banksiana - 1,4-9,1 \%. Останній вид знайдено тільки у двох із п’яти досліджуваних адміністративних районів.

У переважній більшості випадків соснові насадження розміщено на вільних пришляхових територіях на відстані 5-20 м і більше від самої дороги або у скверах біля адміністративних будівель, лікарень, шкіл, а також у парках. Зокрема в одному із них знайдено найстаріші дерева $P$. pallasiana, вік яких досягав 50 років. У пришляхових насадженнях максимальний вік цього виду не перевищував 40 років. 
У пришляхових соснових насадженнях різних районів м. Кривого Рогу зустрічаються дерева віком менше 10 років і трохи більше. Розподіл дерев за віковими групами з інтервалом у 10 років свідчить, що найчисельнішою групою в насадженнях P. pallasiana є вікова група 11-20 років - 135 особин, або 39,7 \% від загальної кількості рослин і 21-30 років - 118 особин, або 34,7 \% (рис. 1а). На дерева 11-30-річного віку у пришляхових насадженнях P. pallasiana припадає 3/4 від загальної їх кількості в насадженнях, а P. sylvestris - 92,4 \% дерев (рис. 1б).
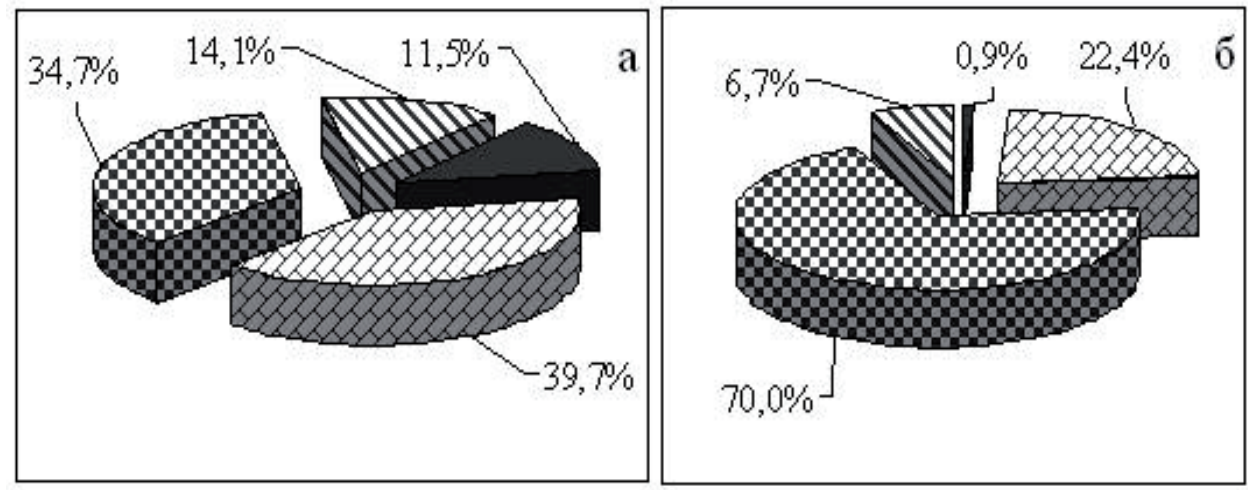

Рис. 1. Вікова структура Pinus pallasiana (a) та Pinus sylvestris (б) у пришляхових насадженнях міста Кривого Рогу

Взагалі це свідчить про скорочення посадок обох видів сосен в останнє десятиріччя: до $0,9 \%$ P. sylvestris i $11,5 \%$ P. pallasiana. В окремих дерев соснових насаджень 20-35-річного віку спостерігаються поява сухих гілок у кроні, зміна форми й щільності крони, пошкодження кори стовбура та гілок, ураження грибковими захворюваннями та шкідниками. P. banksiana в насадженнях міста зустрічається досить рідко, знайдено всього 12 дерев віком 10-20 років, які мали пригнічений вигляд.

В умовах міського парку «Шахтарський» знайдено 45-48-річні дерева P. pallasiana, які досягали 14 м у висоту при максимальному діаметрі стовбура на рівні 1,3 м - 43 см. Поодиноко зростаючі дерева в парку мали кращі біометричні показники, ніж дерева, що зростали в алейних та куртинних насадженнях (табл. 1). Винятком є висота крони, а за всіма іншими показниками поодинокі дерева переважали ті, що зростали в групових паркових насадженнях.

Таблиия 1

Біометричні характеристики дерев $P$. pallasiana в парку м. Кривий Piг

\begin{tabular}{|c|c|c|c|c|c|c|c|c|c|c|c|}
\hline \multirow{4}{*}{ 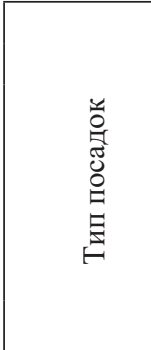 } & \multirow{4}{*}{ 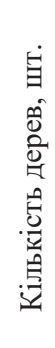 } & \multicolumn{7}{|c|}{ Характеристика } & \multirow[b]{3}{*}{ 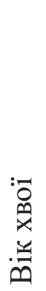 } & \multirow[b]{3}{*}{ 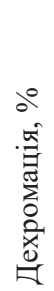 } & \multirow{3}{*}{ 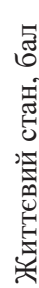 } \\
\hline & & \multicolumn{4}{|c|}{ дерев } & \multicolumn{3}{|c|}{ крони } & & & \\
\hline & & 光 & 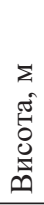 & 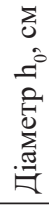 & 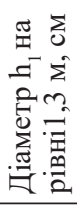 & 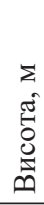 & $\begin{array}{l}\sum_{\Sigma}^{n} \\
\sum_{0}^{n} \\
i \\
0\end{array}$ & $\begin{array}{c}\text { Площа } \\
\text { проекції, } \text { м² }^{2}\end{array}$ & & & \\
\hline & & \multicolumn{10}{|c|}{$\mathrm{M} \pm \mathrm{m}$} \\
\hline Подинокі & 5 & $46,3 \pm 1,1$ & 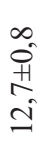 & 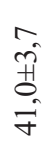 & $\begin{array}{l}\overrightarrow{7} \\
+ \\
m \\
m \\
m\end{array}$ & \begin{tabular}{l}
+ \\
$\stackrel{+}{+}$ \\
$\stackrel{+}{+}$ \\
\multirow{+}{*}{}
\end{tabular} & 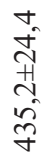 & $100,9 \pm 3,6$ & $\begin{array}{c}\dot{J}_{0} \\
\stackrel{+}{+} \\
\dot{m}\end{array}$ & $\begin{array}{l}0 \\
0 \\
0 \\
0 \\
0 \\
0\end{array}$ & 1 \\
\hline
\end{tabular}


Закінчення табл. 1

\begin{tabular}{|c|c|c|c|c|c|c|c|c|c|c|c|}
\hline \multirow{4}{*}{ 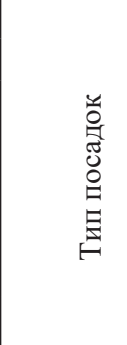 } & \multirow{4}{*}{ 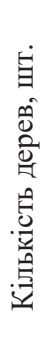 } & \multicolumn{7}{|c|}{ Характеристика } & \multirow[b]{3}{*}{$\begin{array}{l}: \overline{0} \\
\dot{0} \\
x \\
. \breve{n}\end{array}$} & \multirow[b]{3}{*}{ 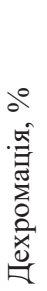 } & \multirow{3}{*}{ 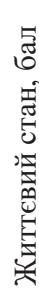 } \\
\hline & & \multicolumn{4}{|c|}{ дерев } & \multicolumn{3}{|c|}{ крони } & & & \\
\hline & & $\stackrel{y}{a}$ & 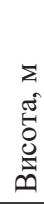 & 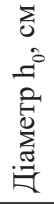 & 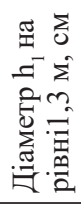 & 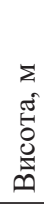 & $\begin{array}{c}\sum^{n} \\
\sum^{j} \\
i \\
0\end{array}$ & $\begin{array}{c}\text { Площа } \\
\text { проекції, } \text { м² }^{2}\end{array}$ & & & \\
\hline & & \multicolumn{10}{|c|}{$\mathrm{M} \pm \mathrm{m}$} \\
\hline Алейні & 25 & $42,4 \pm 0,9$ & 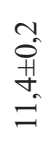 & $\begin{array}{l}0 \\
\text { सु } \\
\dot{m}\end{array}$ & $\frac{\tilde{0}}{\stackrel{+}{\infty}}$ & 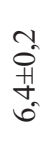 & 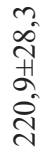 & $34,6 \pm 4,1$ & $\overrightarrow{\overrightarrow{0}}$ & 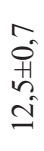 & 1 \\
\hline Куртини & 51 & $45,5 \pm 0,2$ & $\begin{array}{l}\sqrt{0} \\
0 \\
+1 \\
= \\
=\end{array}$ & 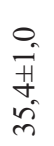 & $\begin{array}{l}\hat{O} \\
\text { +ो } \\
\text { oे } \\
\text { on }\end{array}$ & 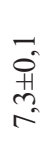 & $\begin{array}{l}0 \\
n \\
m \\
m \\
m \\
n\end{array}$ & $25,6 \pm 1,7$ & $\begin{array}{l}\overrightarrow{0} \\
+ \\
\text { m } \\
m\end{array}$ & $\begin{array}{l}\vec{F} \\
\overrightarrow{+1} \\
\infty\end{array}$ & 1 \\
\hline
\end{tabular}

Як зазначав В. В. Міронов [12], типовим показником стану соснових насаджень і режиму зволоження в посушливій зоні є розміри річного приросту у висоту і в діаметрі. При погіршенні екологічних умов у сосни спочатку зменшується приріст у діаметрі, а потім знижується приріст у висоту.

За даними С. М. Крючкова, найбільш інтенсивний ріст у P. pallasiana спостерігається у віці від 10 до 30 років, а загальне зниження приросту відбувається ближче до 50-річного віку [8]. У Камишині Волгоградської обл. насадження з P. pallasiana, що зростають на пісках, у віці 70 років мали висоту 15 м та діаметр 33 см; на каштанових грунтах цього самого бору P. sylvestris у 100-річному віці мала середню висоту 16,2 м, діаметр $26 \mathrm{~cm}$, а P. pallasiana відповідно 16 м і 32 см [9]. Найбільший приріст за висотою в насадженнях P. sylvestris спостерігається в 10-річному віці; з цього моменту і до 50-річного віку приріст поступово знижується і до 60 років практично закінчується. Досягаючи 105-річного віку, P. sylvestris має пласкі верхівки, що свідчать про закінчення росту. У P. pallasiana найбільший приріст спостерігається у 18 років, а потім 3 даного моменту і до 50-річного віку приріст доволі стабільний. Насадження P. banksiana, які наближалися до 70-річного віку, значно поступалися за ростом P. sylvestris i P. pallasiana [9].

Дослідження біометричних показників пришляхових насаджень P. pallasiana і P. sylvestris у різних районах міста дозволило виявити, що в однакових за віковими категоріями дерев обох видів відмінності статистичних показників (діаметрів деревних стволів та висоти рослин) є несуттєвими (табл. 2).

Так, біометричні характеристики у віковій категорії 15-19 і 25-30 років для насаджень $P$. pallasiana та $P$. sylvestris практично однакові: висота дерева 4,4 і 5,0 м та 9,1 і 9,5 м відповідно, а діаметр стовбура - 15,8 і 16,4 см та 25,5 і 24,9 см відповідно (табл. 2). Насадження P. banksiana характеризуються найменшими біометричними показниками серед інших видів роду Pinus, а саме: висота рослин становить 4,2 м і діаметр стовбурів 8,9 см. Категорію життєвого стану оцінено як «пошкоджені» (табл. 2).

За даними М. М. Дрюченко [5], на Нижньодніпровських пісках 90-річні насадження P. sylvestris мали в середньому висоту 23,6 м, діаметр біля кореневої шийки 55 см і діаметр крони 12,5 см, а насадження P. pallasiana відповідно 10,8 м, 3,5 см і 10,5 см. На супіщаних чорноземах із перегнійним шаром понад 75 см 19-річні насадження $P$. pallasiana мали середню висоту 5,5 м, діаметр на висоті 1,3 м - 7,5 см, а одновікові насадження P. sylvestris відповідно: 9,2 м і 10,9 см. 
Таблиия 2

Вікові групи, кількість дерев у них і їх біометричні характеристики видів роду Pinus L. у пришляхових насадженнях м. Кривого Рогу

\begin{tabular}{|c|c|c|c|c|c|}
\hline \multirow{3}{*}{ Вид } & \multirow{3}{*}{$\begin{array}{c}\text { Вікові } \\
\text { групи, } \\
\text { роки }\end{array}$} & \multirow{3}{*}{$\begin{array}{c}\text { Кількість } \\
\text { дерев, } \\
\text { шт. }\end{array}$} & \multicolumn{2}{|c|}{ Біометричні характеристики } & \multirow{3}{*}{$\begin{array}{l}\text { Життєвий } \\
\text { стан, бал }\end{array}$} \\
\hline & & & висота дерева (h), м & діаметр стовбура (D),см & \\
\hline & & & \multicolumn{2}{|c|}{$\underline{\mathrm{M} \pm \mathrm{m}}$} & \\
\hline \multirow{6}{*}{ P. pallasiana } & $6-10$ & 12 & $\frac{1,5 \pm 0,1}{28,4}$ & $\frac{7,1 \pm 0,5}{24,4}$ & 1 \\
\hline & $12-13$ & 90 & $\frac{4,0 \pm 0,1}{27,1}$ & $\frac{11,9 \pm 0,5}{43,1}$ & 1 \\
\hline & $15-19$ & 60 & $\frac{4,4 \pm 0,1}{18,8}$ & $\frac{15,8 \pm 0,4}{20,0}$ & 1 \\
\hline & $20-25$ & 30 & $\frac{5,6 \pm 0,2}{19,5}$ & $\frac{23,4 \pm 1,2}{28,8}$ & 1 \\
\hline & $25-30$ & 141 & $\frac{9,1 \pm 0,2}{32,1}$ & $\frac{25,5 \pm 0,7}{31,4}$ & 1 \\
\hline & $30-35$ & 6 & $\frac{11,5 \pm 0,5}{10,6}$ & $\frac{31,5 \pm 1,1}{8,5}$ & 1 \\
\hline \multirow{3}{*}{ P. sylvestris } & $15-19$ & 11 & $\frac{5,0 \pm 0,4}{24,5}$ & $\frac{16,4 \pm 1,6}{31,6}$ & 2 \\
\hline & $20-25$ & 84 & $\frac{8,1 \pm 0,3}{32,9}$ & $\frac{18,5 \pm 0,6}{28,4}$ & 1 \\
\hline & $25-30$ & 116 & $\frac{9,5 \pm 0,2}{24,4}$ & $\begin{array}{c}24,9 \pm 0,6 \\
24,4\end{array}$ & 1 \\
\hline P. banksiana & $10-20$ & 12 & $\frac{4,2 \pm 0,9}{21,9}$ & $\begin{array}{c}8,9 \pm 10,3 \\
35,6\end{array}$ & 2 \\
\hline
\end{tabular}

Переважна більшість дерев обох видів сосен у насадженнях м. Кривого Рогу були здоровими, хоча зустрічалися й пошкоджені з дехромацією та дефоліацією хвої (рис. 2). Частка рослин P. pallasiana, які мали 5 \%-ний периферійний хлороз хвої другого року життя, склала 49,7 \%, а в середньому $12 \%$-на дехромація хвої 50,3 \%. У P. sylvestris це співвідношення становило 31,9\% і 68,1\% відповідно. У P. banksiana хлоротичність хвої досягала $62 \%$ і частка дерев 3 такою хвоєю становила близько 18 \%. Тривалість життя хвої у дерев P. pallasiana і P. sylvestris в насадженнях, які не зазнають прямого впливу викидів металургійних комбінатів, становить 3-4 роки. Повністю на рослинах зберігається хвоя першого і другого року життя, відмирає лише хвоя третього і особливо четвертого року. Нами було вивчено дефоліацію хвої (з урахуванням іï дехромації) на бокових пагонах обох видів сосен. У P. pallasiana і P. sylvestris показники дефоліації хвої були на одному рівні і значно меншими, ніж у P. banksiana (рис. 2).

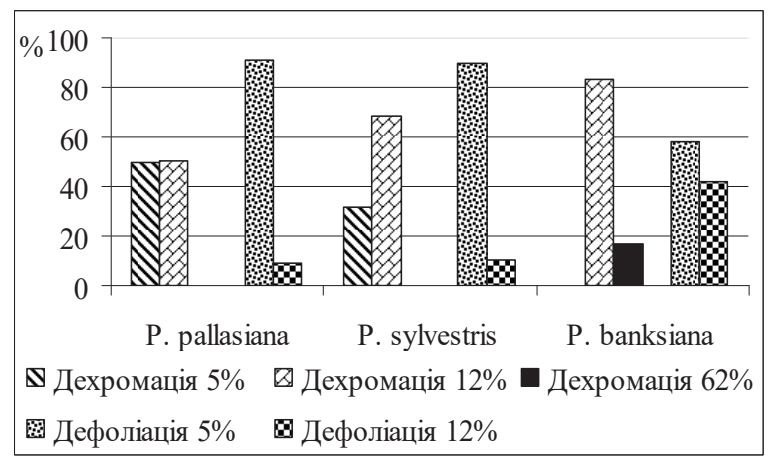

Рис. 2. Дехромація і дефоліація видів роду Pinus L. у пришляхових насадженнях міста Кривого Рогу 
Таким чином, за комплексом досліджуваних показників P. pallasiana i P. pallasiana цілком стійкі до урботехногенного середовища м. Кривого Рогу і мають гарні перспективи для подальшого їх використання в озелененні міста, навіть районів із високим антропогенним навантаженням.

Висновки. У насадженнях м. Кривого Рогу виявлено три види роду Pinus L., 3 яких найбільш представлено P. pallasiana - 340 дерев (60,5\%), P. sylvestris 210 дерев $(37,4 \%)$ і P. banksiana - 12 дерев (2,1\%). У пришляхових насаджень P. pallasiana та P. sylvestris в куртинах і біля адмінбудівель превалюють дерева вікової групи 12-30 років, а у P. banksiana - рослини 10-20 років, які відзначаються високим рівнем життєвості, на відміну від P. banksiana (вік 10- 20 років).

У вікових категоріях 15-19 і 25-30 років у насадженнях P. pallasiana i P. sylvestris суттєвих відмінностей у висоті (h) рослин та за діаметром стовбуpa (D) на висоті 130 см не спостерігається, відповідно для першої вікової групи $\mathrm{h}=4,4 \pm 0,1 \mathrm{M}, \mathrm{D}=15,8 \pm 0,4 \mathrm{~cm}(P$. pallasiana $)$ та $\mathrm{h}=5,0 \pm 0,4 \mathrm{M}, \mathrm{D}=16,4 \pm 1,6 \mathrm{~cm}$ (P. sylvestris). Друга вікова група (25-30 років) - h $=9,1 \pm 0,2 \mathrm{M}, \mathrm{d}=25,5 \pm 0,7 \mathrm{~cm}$ (P. pallasiana) та $\mathrm{h}=9,5 \pm 0,2 \mathrm{~m}, \mathrm{D}=24,9 \pm 0,6$ см (P. sylvestris). В умовах міського парку «Шахтарський» 45-48-річні дерева $P$. pallasiana сягали у висоту 14 м при максимальному діаметрі стовбура 43 см.

В цілому P. pallasiana i P. sylvestris є цілком перспективними для широкого використання в озелененні селітебних територій м. Кривого Рогу.

\section{Бібліографічні посилання}

1. Авдеева $\boldsymbol{E}$. B. Ландшафтно-экологическая среда сибирских городов. Красноярск. СибГТУ. 2006. 124 с.

2. Aвдеева $\boldsymbol{E}$. $\boldsymbol{B}$. Рост и индикаторная роль зеленых насаждений в урбанизированной среде. Красноярск. СибГТУ. 2007. 382 с.

3. Анучин Н. П. Лесная таксация: учебник для вузов. Москва: Лесная промышленность. 1982. 552 с.

4. Артамонов В. И. Растения и чистота природной среды. Москва: Наука. 1986. 172 с.

5. Дрюченко М. М. Производительность сосны крымской на песчаных почвах Украинской ССР. Научные трудыл. Киев. Гос. изд-ва. сельскохозяйственной лит. Украинской ССР. 1954. Вып. 16. С. 126-132.

6. Зайцев $\boldsymbol{\Gamma}$. Н. Математика в экспериментальной ботанике. Москва: Наука. 1990. $296 \mathrm{c}$.

7. Коршиков И. И. Адаптация растений к условиям техногенно загрязненной среды. Киев: Наук. думка. 1996. 238 с.

8. Крючков С. Н., Иозус А. П. Интродукция сосен в Нижнем Поволжье. ВНИАЛМИ. 1978. № 1 (26). С. 43-47.

9. Крючков $\boldsymbol{C}$. H. Опыт интродукции видов рода сосна (Pinus L.) в Нижнем Поволжье. Вестн. Волгогр. гос. ун-та. Сер.11. Естеств. науки. 2015. № 3 (13). С. 18-28.

10. Кузнєцов С. I., Левон Ф. М. Інтродукційна та еколого-ландшафтна оптимізація міських зелених насаджень в Україні. Роль ботанічних садів і дендропарків у збереженні та збагаченні біологічного різноманіття урбанізованих територій: матеріали міжнародної наук. конф. (Київ, 28-31 травня 2013 р.). / Гол. ред. В. Г. Радченко. Київ: НЦЕБМ НАН України. ПАТ «Віпол». 2013. С. 95-97.

11. Лаптєв О. О. Екологія рослин з основами біогеоценології Київ: Фітосоціоцентр. 2001. $144 \mathrm{c}$.

12. Миронов В. В. Облесение песков юго-востока Москва: Лесная пром. 1970. 168 с.

13. Методические рекомендации для оценки восстановительной (балансовой) стоимости зеленых насаждений населенных пунктов Украины. Київ: НИИ УПЖКХ. 1996. 24 с. $240 \mathrm{c}$.

14. Методы изучения лесных сообществ. Санкт-Петрбург НИИ химии СПб. ГУ. 2002.

15. Методичні рекомендації з моніторингу лісів України. Харьков: УкрНДІЛГА. 2009. $48 \mathrm{c}$.

16. Поляков $\boldsymbol{A} . \boldsymbol{K}$. Интродукция древесных растений в условиях техногенной среды. Донецк: Ноулидж. 2009. 268 с. 
17. Соломаха Н. Г., Поляков О. К., Суслова О. П. Випробування видів сосен у Донецькому ботанічному саду НАНУ: результати та перспективи. Лісівництво і агролісомеліораиія. Х.: УкрНДІЛГА. 2009. Вип. 116. С. 200-203.

18. Ярмишко В. T. Диагностика повреждений и оценка жизненного состояния деревьев и древостоев в условиях промышленного атмосферного загрязнения. Методы изучения лесных сообществ. Санкт-Петербург: НИИ химии СПбГУ. 2002. С. 154-165.

Надійшла до редколегї 12.07.2016 p.

УДК 202.75:58.006

Б. О. Барановський, В. В. Манюк, І. А. Іванько, Л. О. Кармизова, Д. В. Орищенко

Дніпровський начіональний університет імені Олеся Гончара

\section{АНАЛІЗ РАРИТЕТНОЇ ФЛОРИ ЛІВОБЕРІЖЖЯ ДОЛИНИ р. ОРІЛЬ}

Наведено аналіз раритетної фракції флори судинних рослин лівоберіжжя долини р. Оріль лісових екосистем долинно-терасових ландшафтів на території запроектованого національного парку «Орільський». На території лівоберіжжя долини р. Оріль у лісових екосистемах виявлено 1 вид - із Світового червоного списку, 1 вид із Європейського червоного списку, 6 видів - із Червоної книги України, із Червоного списку Дніпропетровської області - 53 види. Доля рідкісних та зникаючих видів лісових екосистем від всієї раритетної флори (140 видів) дослідженої території складає 30 \%, що свідчить про созологічну цінність лісових екосистем долинно-терасових ландшафтів Степової зони України, які, незважаючи на багаторічну антропогенну трансформацію, зберегли достатній рівень фіторізноманіття.

У процесі досліджень флори долини р. Оріль виявлено низку нових місцезнаходжень рідкісних для області та регіону видів.

Ключові слова: аналіз раритетної флори, фіторізноманіття, судинні рослини, екосистеми.

\section{Б. А. Барановский, В. В. Манюк, І. А. Иванько, Л. А. Кармызова, Д. В. Орищенко \\ Днепровский национальній университет имени Олеся Гончара \\ АНАЛИЗ РАРИТЕТНОЙ ФЛОРЫ ЛЕВОБЕРЕЖЬЯ ДОЛИНЫ р. ОРЕЛЬ}

Приведен анализ раритетной фракции флоры сосудистых растений левобережья долины р. Орели лесных экосистем долинно-террасных ландшафтов на территории запроектированного национального парка «Орельский». На территории левобережья долины р. Орели в лесных экосистемах обнаружены 1 вид - из Мирового красного списка, 1 вид из Европейского красного списка, 6 видов из Красной книги Украины, из Красного списка Днепропетровской области - 53 вида. Доля редких и исчезающих видов лесных экосистем от всей раритетной флоры (140 видов) исследованной территории составляет 30 \%, что свидетельствует о созологической ценности лесных экосистем долинно-террасных ландшафтов Степной зоны Украины, которые, несмотря на многолетнюю антропогенную трансформацию, сохранили достаточный уровень фиторазнообразия. В процессе исследований флоры долины р. Орели обнаружен ряд новых местонахождений редких для области и региона видов.

Ключевые слова: анализ раритетной флоры, сосудистые растения, фиторазнообразие, экосистемы.

(C) Б. О. Барановський, В. В. Манюк, І. А. Іванько, Л. О. Кармизова, Д. В. Орищенко, 2017 